\title{
Determination of stocking density limits for Crassostrea gigas larvae reared in flow-through and recirculating aquaculture systems and interaction between larval density and biofilm formation
}

\author{
Katia Asmani ${ }^{1}$, Bruno Petton ${ }^{1}$, Jacqueline Le Grand ${ }^{1}$, Jérôme Mounier ${ }^{2}$, René Robert ${ }^{1}$ and \\ Jean-Louis Nicolas ${ }^{1, *}$ \\ ${ }^{1}$ Ifremer, Laboratoire des Sciences de 1'Environnement Marin, UMR 6539 LEMAR (UBO/CNRS/IRD/Ifremer), \\ Centre de Bretagne, CS 10070, 29280 Plouzané, France \\ ${ }^{2}$ Université de Brest, UEB, EA3882 Laboratoire Universitaire de Biodiversité et Ecologie Microbienne, \\ IFR148 ScInBioS, ESIAB, Technopôle de Brest-Iroise, 29280 Plouzané, France
}

Received 2 January 2017 / Accepted 8 June 2017

Handling Editor: Verena Trenkel

\begin{abstract}
The first aim of this study was to determine the stocking density limits for Pacific oyster Crassostrea gigas larvae reared in flow-through system (FTS) and recirculating aquaculture systems (RAS). The second aim was to examine biofilm formation on the larval tank wall and its interaction with larvae growth. Three larvae concentrations were tested: 50,150 , and $300 \mathrm{~mL}^{-1}$. Chemical parameters and larvae performance were measured. The biofilm was observed by scanning electron microscopy, and its bacterial composition was investigated by pyrosequencing analysis of part of the $16 \mathrm{~S}$ rRNA gene. The highest growth $\left(13 \mu \mathrm{m} \mathrm{day}{ }^{-1}\right)$, survival (87\%) and metamorphosis (50\%) rates were observed in FTS at 50 larvae $\mathrm{mL}^{-1}$, while lower and similar performances occurred at 150 larvae $\mathrm{mL}^{-1}$ in both systems. At 300 larvae $\mathrm{mL}^{-1}$, performances dropped with occurrence of mortality. Biofilm thickness increased with larval density. The pioneer bacteria were coccobacilli followed by filamentous bacteria. The latter constituted abundant braids at the end of rearing at high larval concentrations. The first colonizers were mainly Rhodobacteraceae ( $\alpha$-Proteobacteria). The filamentous bacteria were Saprospirae (Bacteroidetes) and Anaerolineae (Chloroflexi). The biofilm was also made up of other minor groups, including Actinobacteria, Planctomycetes, $\delta$-, $\gamma$-Proteobacteria, and Flavobacteriales. The biofilm's composition was more similar to that found in a sewage reactor than in open-sea collectors, which might negatively influence larval rearing due to potential metabolites. This first study on biofilms provides insights into the interaction between rearing density and larvae performance.
\end{abstract}

Keywords: Pacific oyster / Larval culture / High stocking density / Biofilm / Filamentous bacteria

\section{Introduction}

Marine biofilms have mainly been studied on the surface of man-made structures, where they can cause serious damage such as fouling and corrosion (Dobretsov, 2009; Salta et al., 2013; Usher et al., 2014; Zarasvand and Rai, 2014). Biofilms have also been found to have numerous positive effects in a large range of ecosystems (Anderson, 2016). At the seawatersediment interface, they contribute to biogeochemical cycles (Moya et al., 2012). When a biofilm colonizes the surface of

\footnotetext{
* Corresponding author: $j 1$.nicola@ifremer.fr
}

macro-algae (Miranda et al., 2013) or animals such as cnidarians (Golberg et al., 2013), it can contribute to their development and defense (Bernbom et al., 2011). Biofilms also favor the attachment and metamorphosis of bivalves and other organisms (Anderson and Epifanio, 2009; Ganesan et al., 2010; Tebben et al., 2011; Yang et al., 2016a, b, 2017). In aquaculture, biofilms have not been well studied up to now (Li et al., 2014; Yang et al., 2013), except in bioreactors of recirculating aquaculture systems (RAS). Several authors have studied heterotrophic bacteria and autotrophic nitrifying bacteria involved in the depuration of waste seawater to understand their interaction and functioning (Schneider et al., 2007; Foesel et al., 2008; Gao et al., 2012). For shrimps reared 


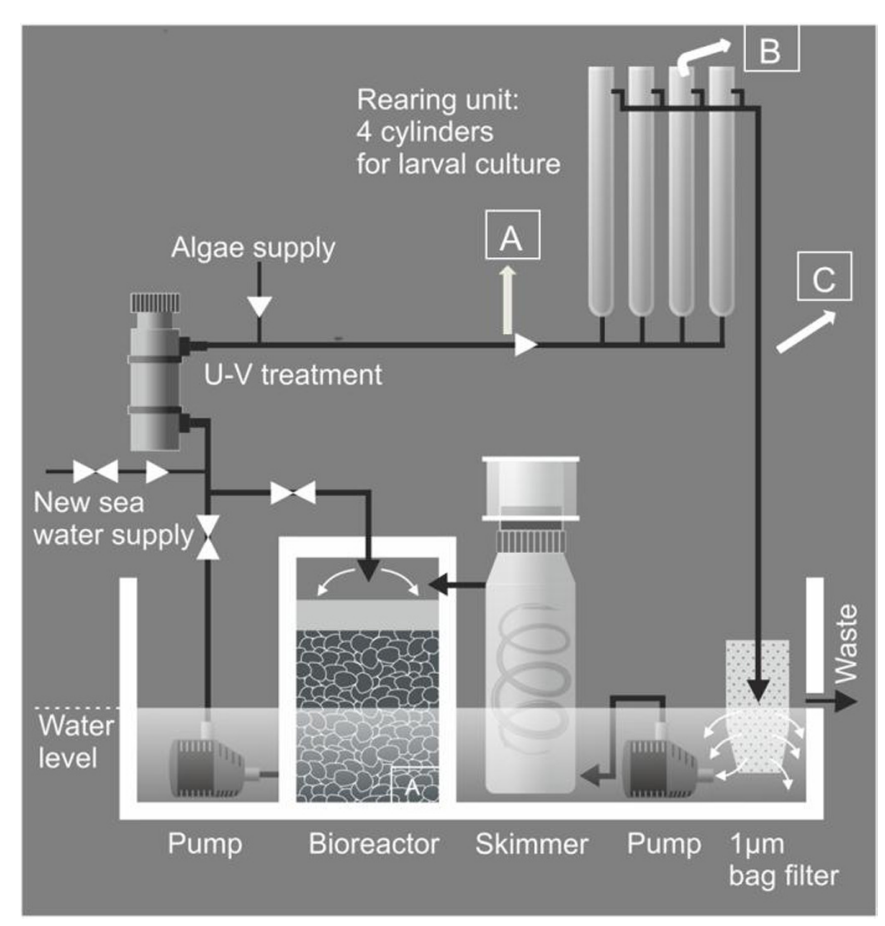

Fig. 1. Schematic view of larval rearing systems. The sampling locations are indicated by arrows and letters $(\mathrm{A}=$ inlet seawater, $\mathrm{B}=$ biofilm, $\mathrm{C}=$ outlet seawater).

in ponds, the biofilm constitutes an essential complementary food source (Viau et al., 2013; Gatune et al., 2014). The pathogenic bacteria of biofilm on a rearing tank wall have also been investigated for prophylactic purposes (Cai et al., 2008, 2013). In fish aquaculture, heterotrophic bacteria growing in biofilms reached up to $1.5 \times 10^{7} \mathrm{CFU} \mathrm{cm}^{-2}$ (Leonard et al., 2000; Rurangwa and Verdegem, 2015). Despite the high bacterial biomass of biofilms, no study has yet attempted to estimate the positive or negative role in rearing systems, especially larval rearing, except for pathogenic bacteria (Cai et al., 2013).

In bivalve hatcheries, larvae are reared at stocking densities between 5 and 20 larvae $\mathrm{mL}^{-1}$ depending on species and larval age, which generates very little organic matter $(\mathrm{OM})$, and as a result biofilms should not play an important role in recycling OM (unpublished data).

Since the 2000s, the flow-through system (FTS) has been improved (Rico-Villa et al., 2008; da Costa et al., 2015) to increase larval concentrations from 5 to 100 larvae $\mathrm{mL}^{-1}$. A stocking density of 50 larvae $\mathrm{mL}^{-1}$ is currently generally used for rearing, but without knowing the actual limits of this concentration. The second aspect in the improvement of bivalve larvae culture has been to recycle outlet seawater to economize heating energy. In these more intensive systems, bacterial proliferation in seawater is limited by continuous and rapid seawater renewal as well as by ultraviolet (UV) treatment of inlet seawater. Therefore, the quantity of dissolved and particulate OM could significantly increase and provide a high quantity of nutrients to fixed bacteria as has been found in fish aquaculture (Blancheton et al., 2013). In these conditions, the role of biofilms needs to be reconsidered. In a recent study, Asmani et al. (2016) examined bacterial communities associated with different compartments of FTS and RAS including seawater, larvae, and bioreactor but not the biofilm on the tank wall.

In this study, the optimal value and limit of larvae stocking density were determined in FTS and RAS experimentally at three larval concentrations. In each case, the biofilm was examined to investigate the steps of its formation, estimate its importance and composition, and begin to elucidate its potential role in intensive larvae rearing systems.

\section{Materials and methods}

\subsection{Experimental design}

The experiment was performed using two different rearing systems, FTS and RAS, at the IFREMER experimental station in Argenton (Brittany, France) and three larval concentrations: 50,150 , and 300 larvae $\mathrm{mL}^{-1}$. The stocking density of 50 larvae $\mathrm{mL}^{-1}$ was used as a control, since it has already been validated in previous experiments (da Costa et al., 2015; Asmani et al., 2016). Overall, four treatment experiments denoted FT150, FT300, RS150 and RS300, and two control experiments, denoted FT50 and RS50, were carried out.

Wild broodstock was collected from Aber Benoit (Brittany, France) and transferred to the Argenton hatchery facilities for conditioning. Individuals were placed in open-flow tanks at $19^{\circ} \mathrm{C}$ where they were maintained for two months. They received a daily mixed diet of Tisochrysis lutea and Chaetoceros neogracile, equivalent to $6 \%$ of oyster dry weight in dry weight of algae per day.

Gonads of the broodstock were stripped for gamete collection, using ten males and eight females. After counting, fertilization was performed at a ratio of 50 spermatozoa per oocyte. Two hours later, the embryos were incubated in cylindroconical tanks in $1-\mu \mathrm{m}$-filtered seawater at $22^{\circ} \mathrm{C}$. After $48 \mathrm{~h}$ of incubation, the percentage of D-larvae was determined. Veligers were transferred to 5-L translucent, methacrylate cylinders and reared, in four replicates, in an FTS as described by Gonzalez-Araya et al. (2012) and da Costa et al. (2015). A continuous seawater inflow of $0.87 \mathrm{~mL} \mathrm{~min}^{-1}$ was provided at the bottom of each experimental tank $(100 \%$ tank water renewal per hour). Food was delivered by pumping from a reservoir, which was cleaned and filled with the appropriate feed daily, directly to the larval tanks down the seawater line. Seawater was $1-\mu \mathrm{m}$-filtered and UV-treated. Temperature was maintained at $25^{\circ} \mathrm{C}$ using a thermo-regulated automatic valve, and ambient salinity was 34.5 . In each tank, aeration, provided from the bottom to maximize water circulation, was set at $30 \mathrm{~mL} \mathrm{~min}^{-1}$. The outlet of each tank was equipped with a beveled polyvinyl chloride pipe as a sieve to prevent larvae from escaping. Sieve mesh sizes of 40,60 , and $80 \mu \mathrm{m}$ were used at the beginning of the experiment on days 6 or 7 , and day 10, respectively. The larvae were fed with two microalgae, Isochrysis affinis galbana (T. Iso = strain CCAP 927/14) and Chaetoceros gracilis (Utex LB 2375) at $1500 \mu^{3} \mu^{-1}$ (at 1:1 equivalent volume). The volume of algal culture continuously supplied to the systems was adjusted to the requirement of larvae, as estimated by the algal cells left in the outflow seawater. It varied from around $50 \mathrm{~mL} \mathrm{day}^{-1}$ on day $4-800 \mathrm{~mL}^{-1 a y}{ }^{-1}$ on day 15 with 50 larvae $\mathrm{mL}^{-1}$ in FTS. The total volume of algal culture distributed during a run was around $24 \mathrm{~L}$. The 5 -L cylinders of the other 
batches received the following amounts over the whole period of larval rearing: $73 \mathrm{~L}$ (FT150), $122 \mathrm{~L}$ (FT300), 27 L (RS50), 70 L (RS150), and $127 \mathrm{~L}$ (RS300).

A similar unit of four cylinders was used for the RAS, which was connected to a recycling loop to treat the outflow seawater (Fig. 1). The remaining algae and particles were trapped on a $1-\mu \mathrm{m}$ cotton bag filter, and the seawater was then pumped to circulate several times through the skimmer and a nitrifying bioreactor filled with plastic beads of $55 \mathrm{~mm}$ diameter with a total surface of $300 \mathrm{~m}^{2} \mathrm{~m}^{-3}$. A second pump distributed a small amount of treated seawater to the unit of cylinders, after UV disinfection to prevent bacterial contamination and limit bacterial proliferation. The rest of the water was returned to the bioreactor. The total volume of the system, including the four cylinders and treatment unit, was around $40 \mathrm{~L}$. The rate of seawater circulation through the RAS rearing tank was the same as through the FTS described above, i.e., $100 \%$ or $5 \mathrm{~L}$ per hour with $10 \%$ fresh seawater and $90 \%$ recycled seawater. The fresh sea water was treated in the same manner as for the FTS.

To enable the establishment of nitrifying autotrophic bacteria in the bioreactor prior to larval culture, unsterilized seawater enriched once per week with $\sim 10 \mathrm{mg} \mathrm{L}^{-1}$ ammonium hydroxide was circulated through the bioreactors for 1.5 months. Nitrification was verified by regular ammonium, nitrite, and nitrate measurements. Before the larvae were added to the system, the bioreactor was rinsed with UV-treated seawater.

Towards the end of the pelagic cycle (15-19 days), the larvae, which by now had a foot, developed a pigmented spot known as an eye (Ben Kheder et al., 2010b). Selective sieving was made on a sieve of $225 \mu \mathrm{m}$ mesh size. The selected larvae were returned to the water at a density of 2 pediveligers $\mathrm{mL}^{-1}$ in 30-L tanks in which $15 \mathrm{~cm}$ diameter plastic discs for settlement had been placed. The rearing conditions were similar to those maintained during larval development.

\subsection{Rearing parameters}

Larval rearing lasted 15 days after hatching. On day 15 , larval survival was determined from a sample of at least 200 larvae after draining and homogenizing the total larval population in each tank. Larval growth was estimated by measuring the shell length of 100 larvae per replicate every 2-3 days using image analysis techniques (Ben Kheder et al., 2010a). Ten days after the end of larval rearing, the percentage of metamorphosis was derived from the number of free non-settled larvae (swimming and dead). The larvae and postlarvae were systematically checked for a possible presence of the OsHv-1 virus according to the method described by Petton et al. (2013).

Chemical water parameters $(\mathrm{pH}$, temperature, salinity, $\mathrm{NH}_{4}{ }^{+}, \mathrm{NO}_{2}{ }^{-}$, and $\mathrm{NO}_{3}{ }^{-}$) were measured in the rearing systems with a Multiparameter Bench Photometer HI 83200 using cadmium reduction, iron sulfate, and adapted Nessler methods, respectively. Water temperature, salinity, $\mathrm{pH}$, and dissolved oxygen were recorded using a multi-parameter system connected to a multi-sensor probe (HI 9828).

\subsection{Cultivable bacteria counts}

On days $2,4,7,10$, and 15 , total cultivable bacteria and vibrio concentrations in inflow and outflow seawater were estimated by counting CFU on agar plates using marine agar
(Difco) and thiosulfate-citrate-bile salts-sucrose medium (TCBS, Difco), respectively. The seawater was diluted tenfold in sterile seawater, and $0.1 \mathrm{~mL}$ was plated. The plates were incubated aerobically at $25^{\circ} \mathrm{C}$ for 4 days (marine agar) or 2 days (TCBS).

\subsection{Scanning electron microscopy (SEM)}

To examine the formation of biofilm on tank walls, small pieces of the same material $(1 \mathrm{~cm} \times 10 \mathrm{~cm}$, methacrylate $)$ as used for the cylinder were folded along their outer edge in order to be held at the edge of the cylinder and fixed to the tank wall. Around $5 \mathrm{~cm}$ of the plates were immersed in water, and three $1 \mathrm{~cm} \times 1 \mathrm{~cm}$ squares were precut from the lower end. These square pieces were sampled individually at different sampling dates (days 7, 11, and 15) for morphological and molecular analyses. One replicate of each rearing unit was equipped with two biofilm collectors, while the others were not. They did not disturb the rearing, since no difference in larval performances was observed between both types of replicates. Two pieces were used by batch for SEM and the other for pyrosequencing. Only one sample was analyzed per compartment and experimental condition as previous analysis by denaturing high performance chromatography on two replicates (two cylinders) per rearing unit showed that these had the same molecular fingerprint. This could be explained by the fact that each cylinder of the same rearing unit received the same seawater. A square piece of methacrylate per batch and sampling date was critical-point dried in a CPD $0301 \mathrm{Bal}-\mathrm{Tec}$ Critical Point Dryer (Metallium SCD 040 Balzers Union, Liechtenstein) using $\mathrm{CO}$ and then mounted on aluminum stubs and coated at $20 \mathrm{~mA}$ with a gold/palladium alloy using a Scancoat 6 sputter coater (Edwards Ltd, Crawley, UK). Images were acquired using an SEM (Quanta 200, FEI company, Oregon, USA).

\subsection{Analysis of bacterial populations by 454 pyrosequencing}

To analyze bacterial community composition, square pieces were collected on days 7, 11, and 15 in the FTS and RAS with 50 (control) and 300 larvae $\mathrm{mL}^{-1}$.

The small pieces of methacrylate were treated with an extraction buffer containing Tris-EDTA-SDS: $40 \mathrm{mM}$ EDTA, $50 \mathrm{mM}$ Tris (TRIZMA Base, $\mathrm{pH} 8.3$ ), and sodium dodecyl sulfate (SDS) $1 \%$. An aliquot of $500 \mathrm{~mL}$ of outflow seawater of every batch was taken on day 15 and filtered through sterile $0.22 \mu \mathrm{m}$ pore size polyethersulfone membranes (Pall) to collect bacteria. All samples were subsequently frozen at $-80{ }^{\circ} \mathrm{C}$ until required for DNA extraction. The samples were then lysed using a Tris-EDTA-SDS extraction buffer and $20 \mu \mathrm{L}$ proteinase $\mathrm{K}\left(20 \mathrm{mg} \mathrm{mL}^{-1}\right)$ (Sigma, France) and incubated for $1 \mathrm{~h}$ at $65^{\circ} \mathrm{C}$. Total DNA was subsequently extracted with phenol/chloroform/isoamyl alcohol and precipitated with ethanol, as described by Romero et al. (2002). The concentration and purity of DNA were determined at 260 and $280 \mathrm{~nm}$ using a Nanodrop spectrophotometer (ND-1000 Nanodrop technologies, Wilmington, DE, USA).

For pyrosequencing, the variable regions $158 \mathrm{~V} 1-\mathrm{V} 3$ of the 16S rRNA gene were amplified from template DNA using primers tailed each side with the Roche multiplex identifiers, $27 \mathrm{~F}$ 

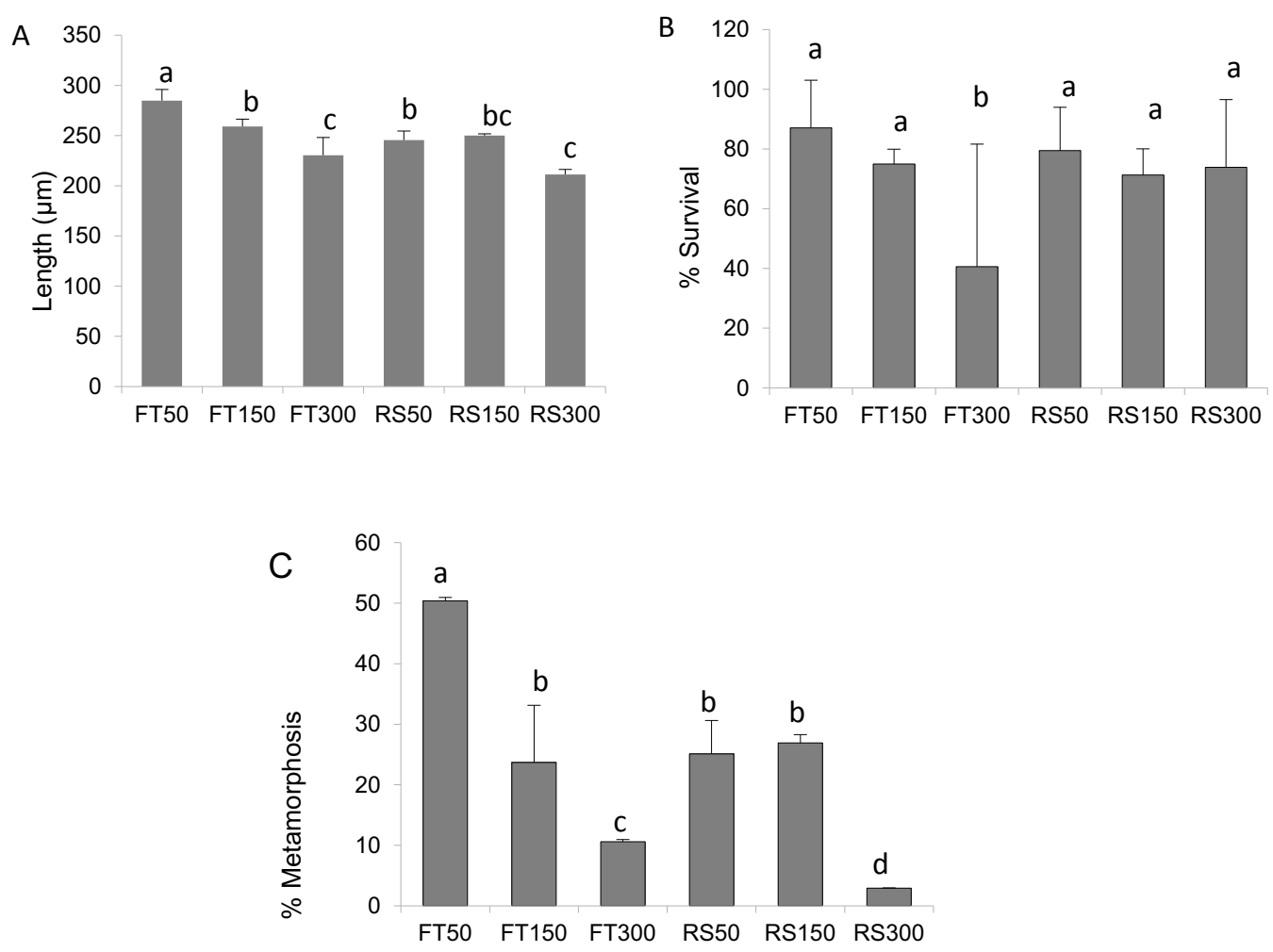

Fig. 2. Growth (A), survival (B), and metamorphosis rates (C) 10 days after the end of larval culture in the different larval concentrations and rearing systems at day 15 . FT, flow through system; RS, recycling aquaculture system. 50, 150, 300: larval concentration $\mathrm{mL}^{-1}(n=4)$. Whiskers indicate \pm SD. Different letters for significantly different results based on post hoc test.

(5'-AGA GTT TGA TCC TGG CTC AG-3', corresponding to Escherichia coli positions 8-27) and 533R (5'-TTA CCG CGG CTG CTG GCA C-3', corresponding to E. coli positions 515533 ), which were modified by the addition of unique barcode sequences to discriminate different samples. Polymerase chain reaction $(\mathrm{PCR})$ mixtures $(50 \mu \mathrm{L})$ were prepared in triplicate and each contained $1 \mu \mathrm{L}$ DNA template, $5 \mu \mathrm{L}$ PCR buffer, $200 \mu \mathrm{M}$ $\mathrm{dNTP}, 0.2 \mu \mathrm{m}$ of each primer, and $2.5 \mathrm{U}$ Taq polymerase (BioTaq, Bioline). PCR reactions were performed as follows: $94{ }^{\circ} \mathrm{C}$ for $5 \mathrm{~min} ; 20$ cycles at $56^{\circ} \mathrm{C}$ for $45 \mathrm{~s}, 72{ }^{\circ} \mathrm{C}$ for $50 \mathrm{~s}$, and then $72^{\circ} \mathrm{C}$ for $10 \mathrm{~min}$. The PCR products were purified with Agencourt AMPure XP (Beckman, USA) and then sequenced by the pyrosequencing method on a 454 Life Sciences Genome Sequencer FLX (Roche Diagnostics, USA). The mixture of PCR products obtained from each sample was sequenced on the GSFLX instrument, thus generating reads from both ends with a read length of $\sim 500 \mathrm{bp}$.

\subsection{DNA sequence processing and analysis}

The composition and diversity of microbial communities of $16 \mathrm{~S}$ rRNA sequence data were determined using the Quantitative Insights Into Microbial Ecology (QIIME, version 1.7.0) pipeline (Caporaso et al., 2010). Raw sequences with an average quality score below 25 and containing more than six ambiguous bases were discarded, as were sequences less than $200 \mathrm{bp}$ or greater than $1000 \mathrm{bp}$ in length and chimeras. No primer mismatch was accepted. The total number of reads obtained after discarding the incorrect sequences was 128837 , with 8589 per sample on average (range 3745-18335). Operational taxonomic units (OTUs) or taxa were chosen using the UCLUST (Edgar, 2010) method and the Greengenes 16S rRNA gene database (version 13.5) as a reference, with a similarity threshold over $97 \%$, resulting in the selection of 12094 OTUs. The overall OTU table was organized by sample to infer separate phylogenetic trees. The resulting pyrosequencing data were deposited in the European Nucleotide Archive (Study accession number: PRJEB12894).

\subsection{Statistical analyses}

Cluster analysis performed using Bray-Curtis similarities in PRIMER 6 software (PRIMER187E, Plymouth, UK) was applied to compare bacterial community structures. A one-way crossed SIMPER test was also conducted to determine which taxa contributed most to the dissimilarity among treatments and sampling dates. Only one sample was analyzed per system and sampling date at 50 and 300 larvae $\mathrm{mL}^{-1}$. Analysis of similarities (ANOSIM) tests were applied grouping samples by sampling date, type of rearing system, or compartment. One-way analyses of variance (ANOVA) were used to test the effect of rearing system and larval density on larval length, survival, metamorphosis rate and algal consumption. When necessary, data were transformed $(\arcsin [\operatorname{sqr}(\times / 100)])$ to respect the homogeneity of residuals. Differences in means were assessed using a posteriori Tukey tests. Linear regressions between larval performance and larval density were fitted. 
Table 1. Linear regression between larval density ( $x: 50,150$ or 300 larvae $\left.\mathrm{mL}^{-1}\right)$ and larval performance in experimental flow-through and recirculation raising system.

\begin{tabular}{|c|c|c|c|c|c|c|}
\hline \multirow[t]{2}{*}{ Performance parameter } & \multicolumn{3}{|c|}{ Flow-through system } & \multicolumn{3}{|c|}{ Recirculation system } \\
\hline & $n$ & Linear regression & $r^{2}$ & $n$ & Linear regression & $r^{2}$ \\
\hline Growth rate & 12 & $15.6-0.022 x$ & 0.79 & 12 & $12.81-0.011 x$ & 0.694 \\
\hline Survival rate & 12 & $1.451-0.0038 x$ & 0.48 & 12 & Not linear & \\
\hline Food efficiency & 10 & $1853-3.356 x$ & 0.496 & 11 & $1483-1.17 x$ & 0.68 \\
\hline Metamorphosis rate & 6 & $55.82-0.166 x$ & 0.86 & 6 & $26.45-0.027 x$ & 0.76 \\
\hline
\end{tabular}

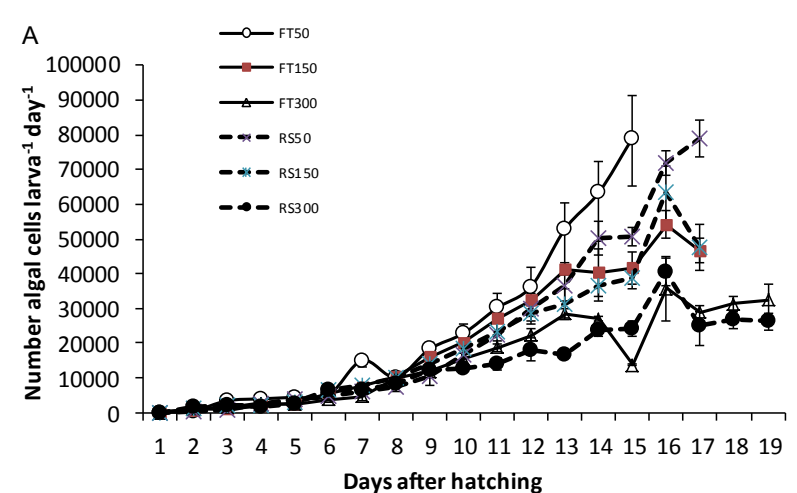

B

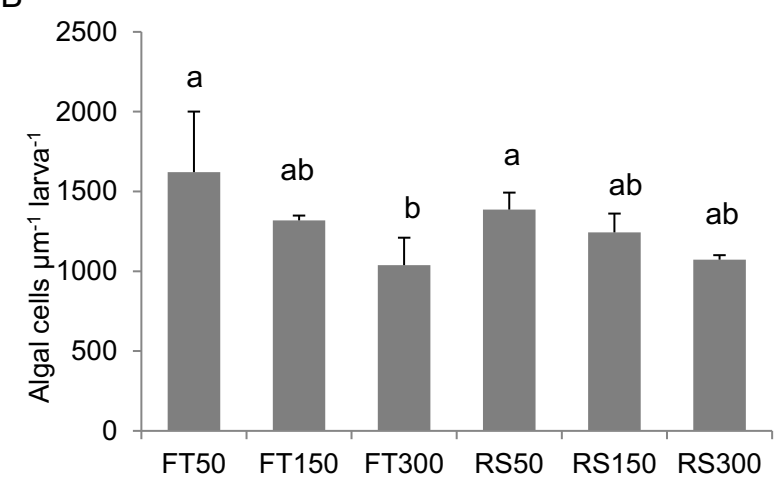

Fig. 3. Algal consumption per larvae per day as a function of age, i.e. rearing time (A) and algal consumption per amount of growth $(\mu \mathrm{m})$ (B). For the legends, see Fig. 2 ( $n=4$ per treatment).

Shannon and evenness indexes were calculated to characterize the structure of bacterial populations.

The Shannon index measures diversity and takes into account the number of individuals as well as the number of taxa. It varies from 0 for communities with only a single taxon to high values for those with many taxa. The evenness index depends on the number of taxa and the number of reads per taxon (dominance). Buzas and Gibson's evenness index is defined as $\mathrm{e}^{\mathrm{H}} / \mathrm{S}$, where $H$ is the Shannon index. $S$ is the number of taxa.

\section{Results}

\subsection{Rearing parameters}

The highest growth rate of $13.7 \mu \mathrm{m} \mathrm{day}^{-1}$ was observed in FTSs with the control larval density (FT50) (Fig. 2A). In flowthrough and recirculation system experiments with larval densities of 50 and $150 \mathrm{~mL}^{-1}$ (RS50, FT150, and RS150), similar growth rates were recorded, ranging from 11.0 to $11.9 \mu \mathrm{m} \mathrm{day}^{-1}$. At 300 larvae $\mathrm{mL}^{-1}$, growth decreased in both systems (around $8.50 \mu \mathrm{mday}^{-1}$ ). Larval growth rate was clearly correlated to larval density in both raising systems (Table 1). Survival rate was not significantly different between rearing conditions, except in FT300 where high mortalities (90\%) affected two replicates (Fig. 2B). Mortalities also occurred in one replicate of RS300 (60\%). Survival rates were correlated with larval density in FTS but not in RAS (Table 1). Food efficiency, estimated as the number of $\mu \mathrm{m}$ of growth algal for 104 algal cells ingested per (Fig. 3B), increased linearly with larval density (Table 1 ). The metamorphosis rate was normal in the FT50 control at around 50\%, but reached only $24-26 \%$ in the RS50 control, as well as in treatments FT150, and RS150, and dropped to $10.6 \%$ and $2.93 \%$ in FT300 and RS300, respectively (Fig. 2C).

Seawater chemical parameters (Table 2) remained stable in all FTS experiments and in RS50 control, whereas $\mathrm{pH}$ decreased to 7.6 and oxygen to $68 \%$ saturation in both RS150 and RS300 treatments. Nitrogen ammonium $\left(\mathrm{N}-\mathrm{NH}_{4}{ }^{+}\right)$in the outflow seawater of RS300 varied between 0.56 and $2.14 \mathrm{mg} \mathrm{L}^{-1}$; high concentrations were found in FTS, up to $0.98 \mathrm{mg} \mathrm{L}^{-1}$. However, ammonia $\left(\mathrm{NH}_{3}\right)$ represented less than $5 \%$ of ammonium at $\mathrm{pH}$ around 8 and was far below the toxicity threshold (around $1 \mathrm{mg} \mathrm{L}^{-1}$, Boardman et al., 2004). The contribution of larval excretion was difficult to estimate, because the concentrations in inlet and outlet seawater were often identical, though varying over time. Nitrite and nitrate remained at very low levels and were even undetectable in RS300. However, prior to larval rearing, the $\mathrm{N}_{-} \mathrm{NO}_{3}{ }^{-}$concentration was high $\left(44 \mathrm{mg} \mathrm{L}^{-1}\right)$ at the end of preparing the nitrifying bioreactor, thus indicating functional nitrification. The cultivable bacterial concentrations did not exceed $10^{5} \mathrm{CFU} \mathrm{mL}^{-1}$ in outflow seawater in either system, regardless of larval density (Fig. 4A and B). However, the total bacteria were multiplied by three to six times during the passage through the larval cylinder. Vibrios on TCBS were systematically below $10 \mathrm{~mL}^{-1}$, except on day 15 in treatment FT300 when they reached $1200 \mathrm{~mL}^{-1}$.

\subsection{Observation in SEM}

The most representative examples of our results are shown in Figure 5. Bacteria adhering to the substrate were not uniformly distributed, but colonized it in patches. Hence observations were targeted at these patches. On day 7, the biofilm in the control (50 larvae $\left.\mathrm{mL}^{-1}\right)$ was constituted of 
Table 2. Extreme chemical parameter values of larval culture in flow-through (FT) and recirculating systems (RS) at larval densities of 50 (control), 150 and 300 larvae $\mathrm{mL}^{-1}$. Measurement were carried out on days 3 and 15, except stated otherwise in brackets. The measurements were done for a mixture of outflow seawater from the four replicates of each rearing unit.

\begin{tabular}{|c|c|c|c|c|c|c|}
\hline Experiment & Day & $\mathrm{O}_{2} \%$ Sat. & $\mathrm{pH}$ & $\mathrm{N}-\mathrm{NH}_{4}$ & $\mathrm{~N}-\mathrm{NO}_{2}$ & $\mathrm{~N}-\mathrm{NO}_{3}$ \\
\hline \multirow[t]{2}{*}{ RS50 } & 3 & 98 & 8.01 & 0.32 & 0.0 & 0.0 \\
\hline & 15 & 92 & 7.89 & 1.18 (day 11 ) & 0.01 & 0.0 \\
\hline RS150 & 15 & 72 & 7.6 & 1.88 & 0.23 (day 7) & 0.7 \\
\hline RS300 & 3 & 98 & 8.01 & 0.56 (day 5) & 0.01 (day 4) & 0.0 (day 4) \\
\hline FT50 & 15 & 92 & 7.98 & 0.96 & 0.03 & 0.00 \\
\hline \multirow[t]{2}{*}{ FT150 } & 3 & 99 & 8 & 0.38 & 0.00 & 0.00 \\
\hline & 15 & 87 & 7.91 & 0.98 & 0.03 & 0.00 \\
\hline \multirow[t]{2}{*}{ FT300 } & 3 & 99 & 7.98 & 0.48 & 0.00 & 0.00 \\
\hline & 15 & 82 & 7.89 & 0.98 & 0.10 & 0.00 \\
\hline
\end{tabular}

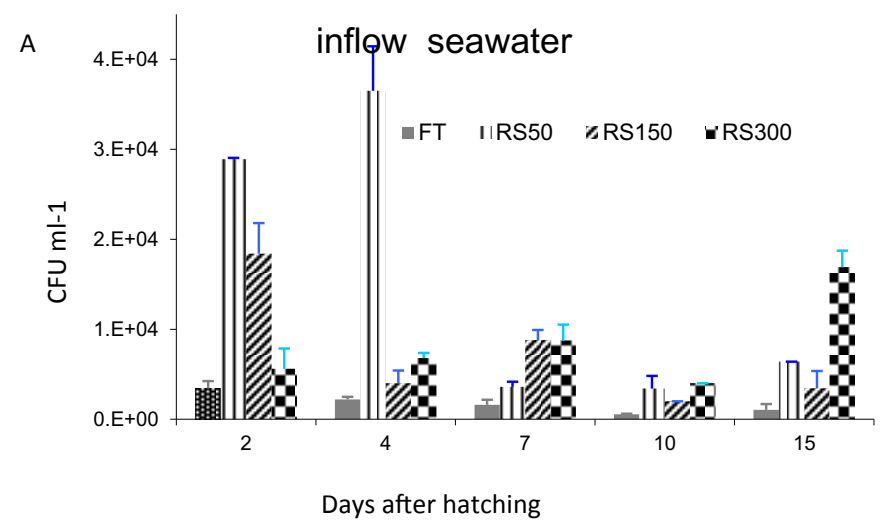

B

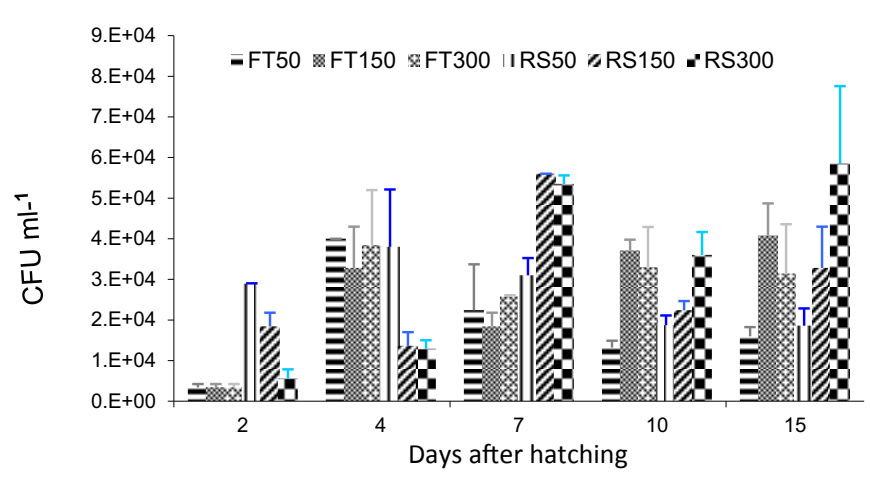

Fig. 4. Concentrations of culturable bacteria in the different rearing conditions in inflow (A) and outflow (B) seawater for three larval density treatments. For the legends, see Fig. $2(n=3)$.

bacillary rods only. Some still possessed their flagella but others had lost them (Fig. 5A and B). These bacteria were isolated or grouped by $2-3$ or sometimes more. They seemed more numerous in RAS than in FTS experiments at this stage. On day 11, the bacteria covered more surface and formed mats in some places in control FT50 where bacterial density appeared higher than in RAS. The very thin filaments and small clumps that linked bacterial cells together were probably EPS (extracellular polymeric substance) (Fig. 5C and D). Filamentous bacteria were established in both systems. In RAS, they were dispersed and had low density (Fig. 5C), whereas in FTS they constituted a weft of filaments in some places (Fig. 5D). Together with the EPS, this weft embedded bacteria and trapped microalgal cells. The cylindrical microalgae may correspond to Chaetoceros neogracile and those with a round shape to Tisochrysis lutea. Coccobacillus were stuck perpendicularly into the filamentous bacteria. In the treatment with 150 larvae $\mathrm{mL}^{-1}$, similar features of biofilm could be observed but with greater density of bacteria. In treatment RS00 on day 15, the filamentous bacteria had formed dense braids with EPS which enveloped all bacteria. Some braids were detached from the surface (Fig. 5E). These filamentous bacteria formed a uniform and dense carpet in some places in treatment FT300 (Fig. 5F). They seemed to be denser in FTS than in RAS.

\subsection{Structure and composition of bacterial communities and their evolution}

The distance matrix (cluster analysis) and its representation by a dendrogram revealed that the bacterial assemblages of biofilm samples from all treatments and controls were relatively similar with $48.7 \%$ similarity on average, compared to only $30.5 \%$ similarity with those of seawater (Fig. 6A). Between the three sampling dates, the bacterial populations in treatment FT50 were more stable with $>54 \%$ similarity on average compared to FT300, which differed more with only $35 \%$ similarity. Changes in the bacterial communities in control RS50 and treatment RS300 were intermediate with $42 \%$ and $49 \%$ similarity, respectively. ANOSIM showed that overall, the bacterial populations of FTS and RAS treatments 
A

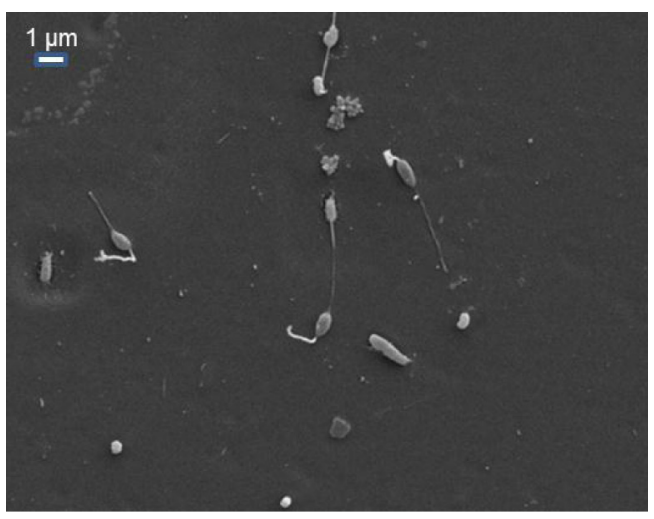

C

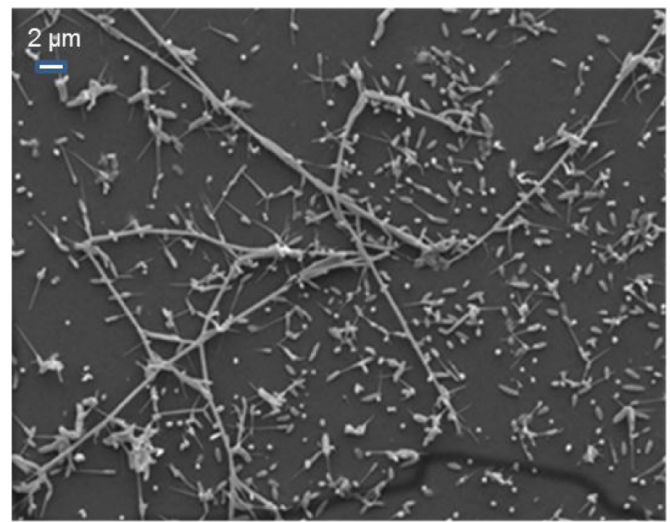

E

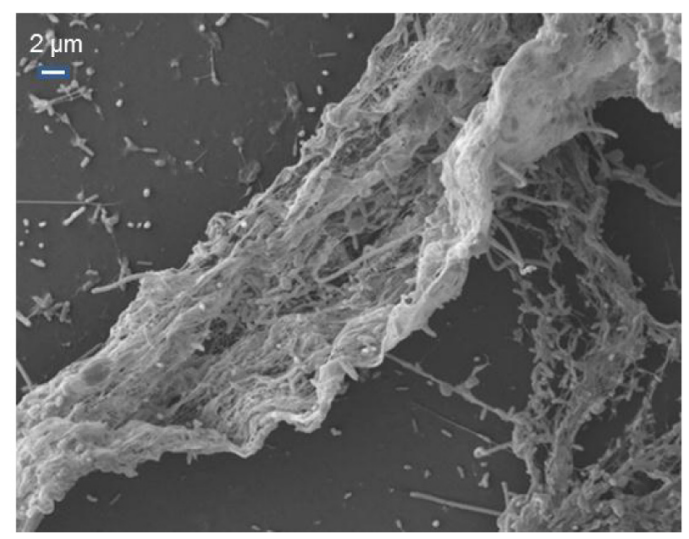

B

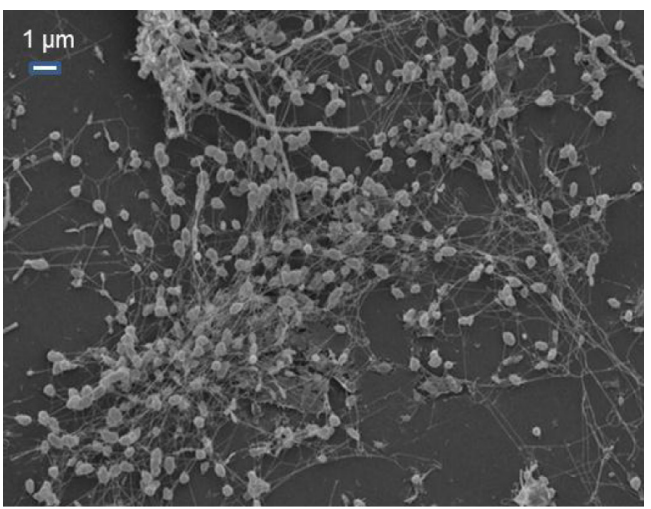

D

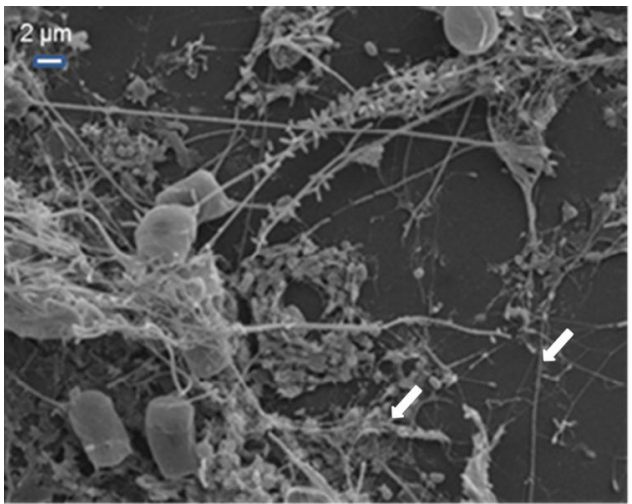

F

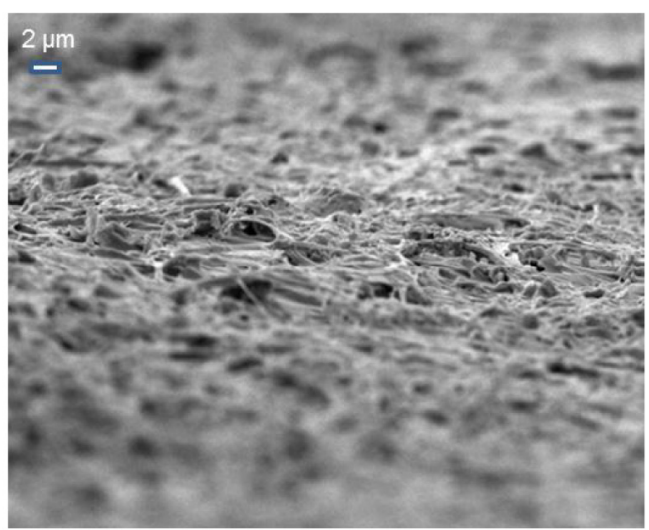

Fig. 5. Scanning electron micrograph photos of biofilms for controls $\left(50\right.$ larvae $\left.\mathrm{mL}^{-1}\right)$ in recycling aquaculture system (RAS) (A and C) and flow-through system (FTS) (B and D) on days 7 and 15, respectively, and treatments with 300 larvae $\mathrm{mL}^{-1}$ on day 15 in RAS (E) and FTS (F). The arrows on photo 5D indicate Extracellular Polymeric Substance (EPS) in the form of aggregates or filaments.

differed, but not among sampling dates. Bacterial populations of seawater and biofilm were clearly different in terms of structure (Table 3).

The number of taxa remained stable at around $138 \pm 28$ (mean \pm standard deviation) regardless of larval density, sampling date, and rearing system, except in FT300 where it tripled between days 7 and 15 to reach 309 taxa. In seawater, the largest number of taxa observed was $180 \pm 9$. The evenness index varied between systems and treatments (Table 4). For
300 larvae $\mathrm{mL}^{-1}$, evenness index was low on day 7 and increased with time. In contrast, evenness index remained low throughout the experiment for control RS50 while for control FT50 it tended to decrease on day 15 following an increase on day 11. Therefore, the dominance of some taxa occurred only during the first few days and progressively disappeared at 300 larvae $\mathrm{mL}^{-1}$, whereas it persisted at lower stocking densities. Shannon index increased with time to reach around 5 , except in control RS50 where it remained stable at around 

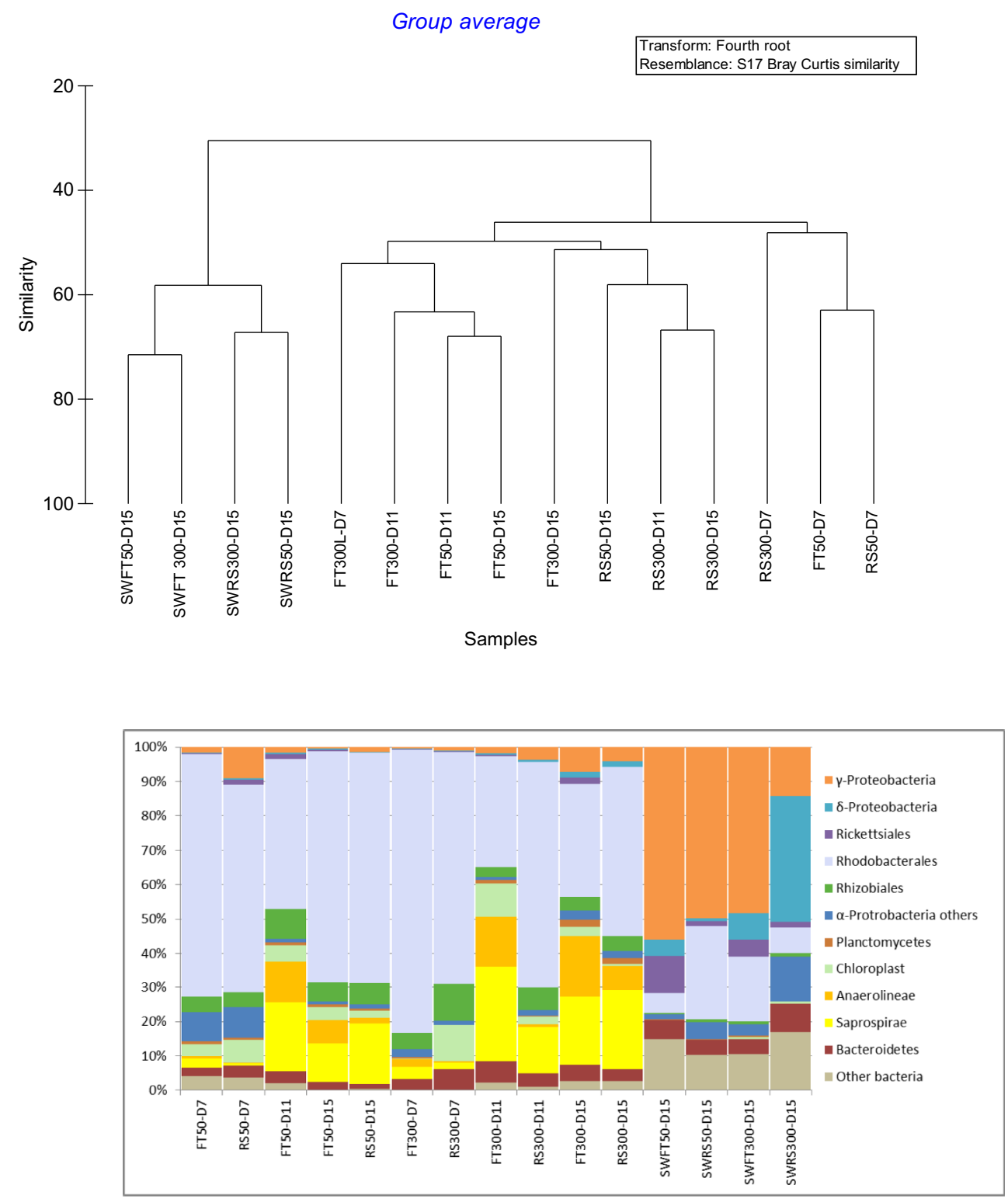

Fig. 6. Comparison of bacterial communities in larvae rearing experiments. Dendrogram built from a cluster analysis of all samples (Bray-Curtis similarity index) (A) and taxonomic composition (B). Samples come from flow-through system (FT), recycling system (RS) or seawater (SW). Larvae concentrations of 50 larvae $\mathrm{mL}^{-1}$ (control) and 300 larvae $\mathrm{mL}^{-1}$ (treatment) on different sampling days (Dx).
3.8 (Table 4). In seawater, Shannon and evenness indexes were close to those of biofilms on day 15 .

The change in bacterial populations between days 7 and 15 was mainly due to an increase in Anaerolineae and Saprospirae and a decrease in some predominant taxa belonging to Rhodobacteraceae: a Ruegeria sp., a Roseovarius sp., and some Phaeobacter spp. (SIMPER analysis, Table 5). The dissimilarity between the biofilms of FTS and RAS was caused by the relative abundance of the same aforementioned bacterial species and groups (Table 5). Finally, no specific bacterial group was linked to a type of rearing system.

On day 7, most of the taxa were affiliated to $\alpha$-Proteobacteria (Fig. 6B). These mainly included Rhodobacterales with some Rhizobiales. Until day 15, these taxa remained at a high level in controls FTS50 and RS50 (above $70 \%$ ), while they decreased in treatments FT300 and RS300 $(35 \%$ and $51 \%$, respectively) and were replaced by
Anaerolineae and Saprospirae. Some taxa belonging to Rhodobacteraceae were predominant mainly during the initial period (days 7 and 11). The $\gamma$-Proteobacteria (2.4-14.1\%) were mainly represented by Alteromonadales without dominance. The Vibrionaceae included in this class were present erratically at very low concentrations $(<0.1 \%)$. They were affiliated to Vibrio aestuarianus and different species inside the Vibrio splendidus clade or to unknown species. Saprospirae and Anaerolineae both increased from around 2\% on day 7 to $31.5-42.0 \%$ in FTS and $14.5 \%$ in RS on day 11 . They probably corresponded to the filamentous bacteria observed using SEM. On day 15, they continued to increase in RS300 and RS50 to reach $30.4 \%$ and $19.2 \%$, respectively. The diversity of these taxa affiliated to both groups of bacteria was high. In all batches, the minor bacterial group Flavobacteriales (Bacteroidetes) ranged from $1.5 \%$ to $6.1 \%$, while Planctomycetes did not exceed $2.3 \%$. 
Table 3. Analysis of similarity (ANOSIM) to validate the significant difference between microbial communities between rearing systems, sampling dates, biofilm and seawater.

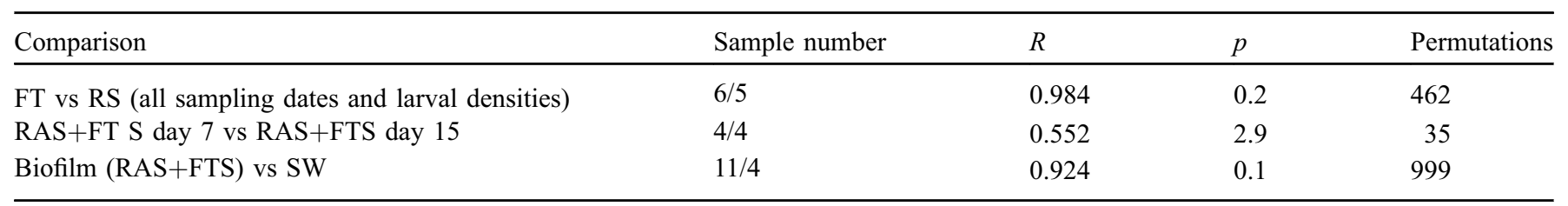

FT, flow-through system; RS, recirculating system; SW, seawater.

Table 4. Diversity; measured by evenness and Shannon indexes, of biofilms at different sampling days $\mathrm{D}(7,11$ and 15$)$ in experimental larval cultures in flow-through (FT) and recirculating system (RS) for controls $\left(50\right.$ larvae $\left.\mathrm{mL}^{-1}\right)$ and treatments $\left(300\right.$ larvae $\left.\mathrm{mL}^{-1}\right)$.

\begin{tabular}{lllll}
\hline Experiment & Biofilm D7 & Biofilm D11 & Biofilm D15 & Seawater D15 \\
\hline Evenness index & & & & \\
FT50 & 0.068 & 0.223 & 0.155 & 0.162 \\
FT300 & 0.098 & 0.209 & 0.276 & 0.235 \\
RS50 & 0.100 & No data & 0.126 & 0.106 \\
RS300 & 0.111 & 0.096 & 0.282 & 0.159 \\
Shannon index & & & 4.80 & 4.72 \\
FT50 & 3.15 & 4.06 & 5.73 & 5.32 \\
FT300 & 3.13 & 4.90 & 3.83 & 4.04 \\
RS50 & 3.85 & No data & 4.97 & 4.67 \\
RS300 & 3.55 & 3.61 & & \\
\hline
\end{tabular}

The presence of microalgae observed in SEM was corroborated by two chloroplast sequences affiliated to a species of Stramenopiles, which may correspond to Chaetoceros neogracile, and a species of Haptophyceae, which may be Tisochrysis lutea. These constituted part of the biofilm for $2-9 \%$ of sequences.

The bacterial populations in outlet seawater were analyzed on day 15 . These populations were similar (61.3 $\pm 6.0 \%$ BrayCurtis similarity). The main contributors to dissimilarity between biofilms of different treatments were Anaerolineae, Saprospirae, $\gamma$-Proteobacteria, $\delta$-Proteobacteria, Rhodobacteraceae ( $\alpha$-Proteobacteria), and unclassified bacteria (Table 5). The bacterial populations of biofilms and outlet seawater shared many identical taxa. Even if the abundance of taxa in every compartment was very different, these common taxa represented $54 \%$ of all taxa in biofilm and $73 \%$ in seawater. They also constituted 74\% (biofilm) and 91\% (seawater) of reads. These identical taxa were mainly affiliated to Flavobacteriales and Rhodobacterales as well as to two unclassified bacteria. Anaerolineae and Saprospirae were specific to the biofilm and were never detected in seawater. The $\gamma$-Proteobacteria, reaching $14.2 \%$ to $51.9 \%$ in seawater, were scarcely represented in biofilms. They were diversified with the main taxa affiliated to Marinomonas spp. (Oceanospirillaceae). Several taxa belonged to Alteromonadaceae were ranged from $6 \%$ to $17 \%$. Some taxa of Vibrionaceae such as Vibrio neptunius occurred but only at very low levels $(<0.1 \%)$. The seawater in control RS50 was differentiated from other seawater samples by a member of Spirobacillales $(\delta$-Proteobacteria), which dominated with $33 \%$ of reads.

\section{Discussion}

In this study, the efficiency of two rearing systems at high larval concentrations was compared experimentally. Both systems correctly functioned until 150 larvae $\mathrm{mL}^{-1}$. A previous experiment using the same FTS with Crassostrea gigas larvae at 50 and 100 larvae $\mathrm{mL}^{-1}$ showed similar results (da Costa et al., 2015), while a comparison between FTS and RAS at 50 larvae $\mathrm{mL}^{-1}$ (Asmani et al., 2016) revealed a growth deficit in RAS. Equivalent performances were previously obtained with an FTS in a 150-L tank (Rico-Villa et al., 2008, 2009). This suggests that the results obtained with a 5-L cylinder should be applicable to the higher volumes used in commercial hatcheries. However, the economic interest of using a stocking density of 150 larvae $\mathrm{mL}^{-1}$ is limited because calories can be saved by plate heat exchangers for FTS and the seawater in RAS is largely recycled. These results showed that at 50 larvae $\mathrm{mL}^{-1}$, the system is far from the threshold of risk. With the aim of optimizing larval rearing, the current FTS at 50 larvae $\mathrm{mL}^{-1}$ is reassessed in this experiment. RAS could interchangeably be used with either 50 or 150 larvae $\mathrm{mL}^{-1}$. However, the final yield of postlarvae was weak due to the low metamorphosis rate whose origin is discussed below.

The difference in the performances of both systems was most marked at 50 larvae $\mathrm{mL}^{-1}$. The recycled seawater in RS50 was likely to result in a growth slowdown. However, the chemical parameters of seawater in the RAS remained stable, being within normal values and equivalent to those recorded in FTS. The RAS seawater possibly contained harmful compounds that disturbed the larval physiology, as reported by 
Table 5. Percentage of the contribution of bacterial groups (SIMPER analysis) to the Bray-Curtis dissimilarity between bacterial populations of different larval rearing systems and sampling days as well as between experiments and seawater.

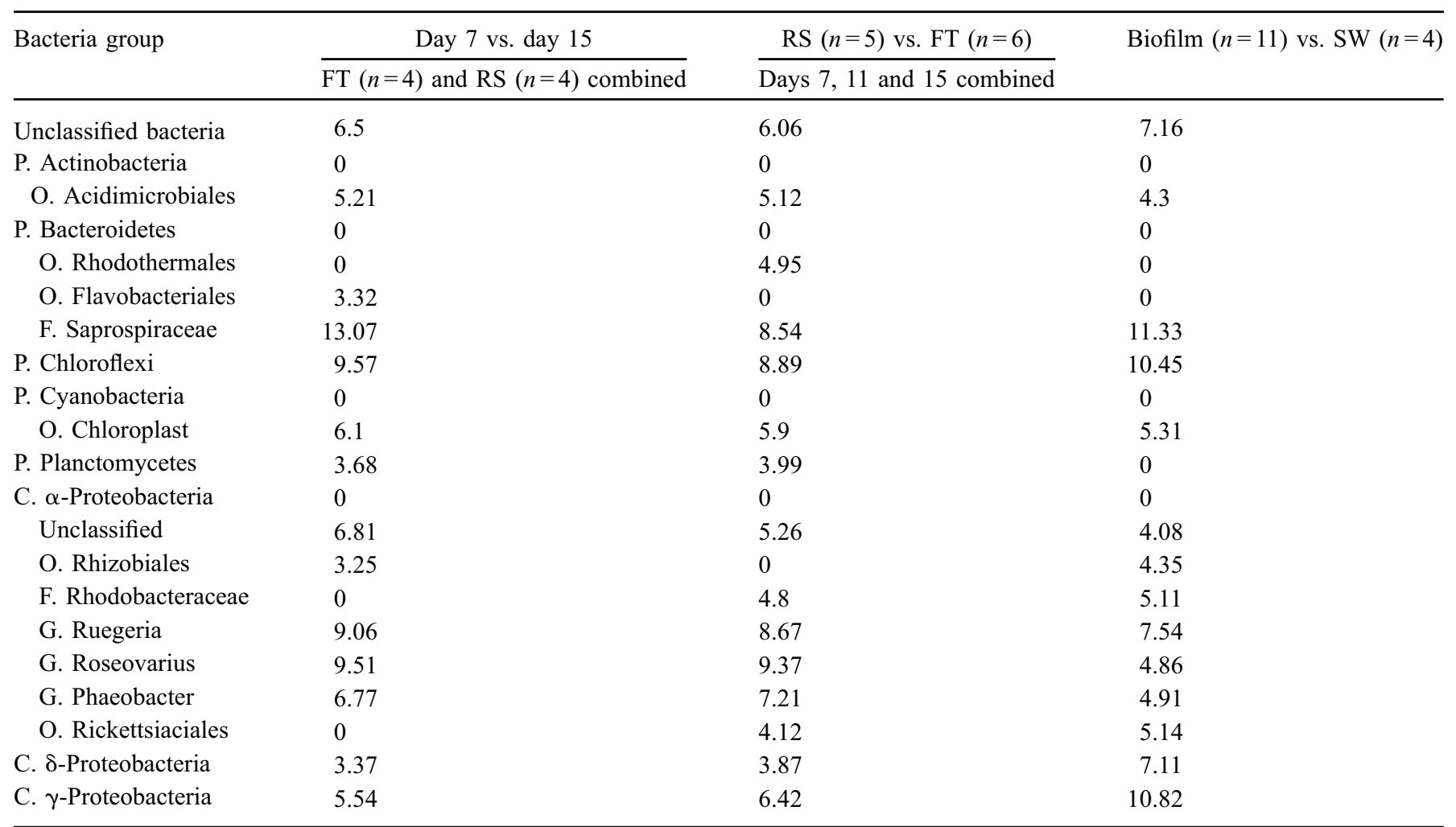

FT, flow-through system; RS, recirculating system; SW, seawater.

Martins et al. (2009) for fish reared in RAS. The fact that the detrimental effects did not increase at 150 larvae $\mathrm{mL}^{-1}$ suggests that toxic compounds could be released by materials used in the manufacturing of the recycling loop, although all components were suitable for aquariology purposes. Another hypothesis is that seawater contained less dissolved organic material (DOM) in terms of both quantity and quality. Indeed, the recycled seawater was certainly impoverished in DOM because of the different treatments used to purify the outlet seawater (i.e., filtration, skimming, bioreactor). Also, the DOM was absorbed by heterotrophic bacteria growing in the recycling loop. This DOM might be a substantial source of nutrients for bivalves (Perez et al., 2013). Other hypotheses such as the detrimental effect of exudates from biofilms are discussed below.

The decline in the growth rate in FTS at 300 larvae $\mathrm{mL}^{-1}$ coincided with a lower ingestion rate of algae in both systems, but it is difficult to know whether this is a cause or an effect. At 150 larvae $\mathrm{mL}^{-1}$, compared to FTS50, the larvae consumed fewer algae per day but the same quantity over the larval rearing period.

At the highest tested larval density, mortalities occurred mainly in the FTS (FT300). Generally, in conventional larval cultures, growth and survival rates decrease above 1020 larvae $\mathrm{mL}^{-1}$ (Robert and Gerard, 1999). The bacterial proliferation favored by the DOM, accumulated fecal matter, and non-ingested food provoke these mortalities, often with an outbreak of vibriosis (Lagos et al., 2015). However, with the rapid renewal of seawater in FTS and RAS, the cultivable bacteria in outflow seawater did not exceed $10^{5} \mathrm{CFU} \mathrm{mL}^{-1}$ and remained equivalent to the bacterial concentrations observed in other experimental conditions. Otherwise, no pathogenic bacterium was detected, except for a peak of vibrios on TCBS in larvae and seawater in FT300 on day 15. This might not be linked to the mortalities, which probably occurred on day 9 when the consumption of microalgae suddenly dropped in the two concerned replicates. A viral disease due to the herpes virus OsHV-1 (Arzul et al., 2001) appeared unlikely, because the other larval batches would have been immediately infected. In addition, larvae and seed were systematically free of this virus in the experimental hatchery of Argenton at this period (Petton et al., 2013). The discomfort caused by the high density could provoke stress, even though it was not observed in mussel larvae until 50 larval $\mathrm{mL}^{-1}$ when measuring the cortisol rate (Lagos et al., 2015). Yet fish aquaculture is known to be very sensitive to stocking density (Herrera et al., 2016). Another detrimental factor could be the biofilm containing filamentous bacteria, which constituted up to $42 \%$ of reads in FT300 on day 11, close to the event of mortality. This suggests the possible toxicity of these filamentous bacteria.

Given its important bacterial biomass, the biofilm could be more active than the bacterial communities associated with seawater, especially in RAS, but it was perhaps less effective on larvae than the microbiota directly associated with them. On the contrary, for the larval rearing of fish, the RAS improved the reliability and performances of larval rearing. This enhancement was attributed to a better control of bacterial populations, notably opportunists with greater diversity and 
stability (Blancheton et al., 2013; Bakke et al., 2015; Attramadal et al., 2014, 2016). In this study, the similarity between the bacterial communities of FTS and RAS did not suggest that they were better equilibrated in RAS. In addition, a few opportunists such as $V$. aestuarianus and Vibrio neptunius were present at very low levels in both systems.

The filamentous bacteria found in this study have not yet been reported in the formation of biofilm in aquaculture systems, particularly in bioreactors (Schneider et al., 2007; Blancheton et al., 2013; Ruan et al., 2015; Asmani et al., 2016). These were however encountered when OM was abundant, as in sludge, wastewater, and sediment ( $\mathrm{Lu}$ et al., 2013; Gonzalez-Gil et al., 2015; Raulf et al., 2015). In the larval culture of oysters, Crassostrea gigas, dissolved organic carbon rarely exceeds $6 \mathrm{mg} \mathrm{L}^{-1}$ (unpublished results), whereas its concentration ranges from 0.2 to $10 \mathrm{~g} \mathrm{~L}^{-1}$ in wastewater or sludge (Zhang et al., 2015; Zhou et al., 2015) and varies from 1.8 to $23 \mathrm{mg} \mathrm{L}^{-1}$ in pore water of sediment (Seidel et al., 2014). Compared to the biofilm in the present study, the biofilms growing on collectors for the fixation of bivalve postlarvae in a natural environment exhibited greater complexity, including prokaryotic and eukaryotic cells but excluding filamentous bacteria (Toupoint et al., 2012; Wang et al., 2012). In our rearing system, the biofilm covering the collectors could be similar to that on a tank wall with a high rate of filamentous bacteria. This may explain the low metamorphosis rate of all batches except for larvae from FT50. In a review of the efficiency of biofilm in the settlement of invertebrate larvae, Hadfield (2011) showed that it was modulated by the presence of favorable, neutral, and unfavorable bacteria.

Members of Saprospirae have been found to be algicidal and bactericidal (Furusawa et al., 2003; Xia et al., 2007). Some bacterial rods found attached perpendicularly to the filamentous bacteria (Fig. 5C and D) resemble those reported in previous studies (Lewin, 1997; Xia et al., 2007). Indeed, Xia et al. (2007) showed that bacteria were caught in mucilage secreted by Saprospira grandis and then digested (ixotrophy). This could explain why at the end of our experiment, in the batches with 300 larvae $\mathrm{mL}^{-1}$, the wefts and braids of filamentous bacteria appeared almost free of coccobacillus. If these Saprospirae can kill prokaryotes and eukaryotes like microalgae, then their active molecules could also affect other eukaryotic organisms such as larvae if they are released into seawater.

Although little is known about Anaerolineae, they have been identified in a broad range of biotopes (Yamada et al., 2005, 2006, 2007; Yamada and Sekiguchi, 2009). Contrary to Saprospirae, no deleterious effect of Anaerolineae has been reported to date.

The quantification of biomass by measuring biofilm thickness and counting bacteria might enable better estimation of bacterial biomass as well as its comparison with other compartments (seawater, larvae) and rearing conditions. The investigation of biofilm could be extended to the different compartments of the recycling loop.

\section{Conclusion}

In conclusion, larval Pacific oyster rearing at high density is reliable until 150 larvae $\mathrm{mL}^{-1}$. However, the decline in performance, primarily of the rate of metamorphosis observed in RAS at 50 larvae $\mathrm{mL}^{-1}$ in comparison with FTS as well as in FTS with increasing density, could limit the use of these conditions unless this problem occurred only by accident. In other experiments, no difference was found in metamorphosis rates at day 30 between both systems (Asmani et al., 2016; unpublished results). The analyzed biofilm could be the cause of these low metamorphosis rates. It could also have negatively influenced larval physiology by impoverishing the seawater in DOM and releasing toxic compounds. Therefore, the biofilm through the significant biomass that it represents could have caused variability in larval rearing. Managing the composition of biofilm through the use of probiotics might improve growth and metamorphosis rates. However, these hypotheses and proposals to control the biofilm require further experiments and analyses to be validated. In all cases, the biofilm should be taken into account when investigating the performance of larval rearing systems.

\section{References}

Anderson JA, Epifanio CE. 2009. Induction of metamorphosis in the Asian shore crab Hemigrapsus sanguineus: characterization of the cue associated with biofilm from adult habitat. J Exp Mar Biol Ecol 382: 34-39.

Anderson OR. 2016. Marine and estuarine natural microbial biofilms: ecological and biogeochemical dimensions. Aims Microbiol 2: 304-331.

Arzul I, Nicolas JL, Davison AJ, Renault T. 2001. French scallops: a new host for ostreid herpesvirus-1. Virology 290: 342-349.

Asmani K, Petton B, Le Grand J, Mounier J, Robert R, Nicolas JL. 2016. Establishment of microbiota in larval culture of Pacific oyster, Crassostrea gigas. Orig Aquacult 464: 434-444.

Attramadal KJK, Minniti G, Oie G, et al. 2016. Microbial maturation of intake water at different carrying capacities affects microbial control in rearing tanks for marine fish larvae. Aquaculture 457: $68-72$.

Attramadal KJK, Thi My Hanh T, Bakke I, Skjermo J, Olsen Y, Vadstein O. 2014. RAS and microbial maturation as tools for $\mathrm{K}$-selection of microbial communities improve survival in cod larvae. Aquaculture 432: 483-490.

Bakke I, Coward E, Andersen T, Vadstein O. 2015. Selection in the host structures the microbiota associated with developing cod larvae (Gadus morhua). Environ Microbiol 17: 3914-3924.

Ben Kheder R, Quere C, Moal J, Robert R. 2010a. Effect of nutrition on Crassostrea gigas larval development and the evolution of physiological indices. Part A: quantitative and qualitative diet effects. Aquaculture 305: 165-173.

Ben Kheder R, Quere C, Moal J, Robert R. 2010b. Effect of nutrition onCrassostrea gigas larval development and the evolution of physiological indices Part B: effects of temporary food deprivation. Aquaculture 308: 174-182.

Bernbom N, Ng YY, Kjelleberg S, Harder T, Gram L. 2011. Marine bacteria from Danish coastal waters show antifouling activity against the marine fouling bacterium Pseudoalteromonas sp Strain S91 and Zoospores of the green alga Ulva australis independent of bacteriocidal activity. Appl Environ Microbiol 77: 8557-8567.

Blancheton JP, Attramadal KJK, Michaud L, d'Orbcastel ER, Vadstein O. 2013. Insight into bacterial population in aquaculture systems and its implication. Aquacult Eng 53: 30-39.

Boardman GD, Starbuck SM, Hudgins DB, Li X, Kuhn DD. 2004. Toxicity of ammonia to three marine fish and three marine invertebrates. Environ Toxicol 19: 134-142. 
Cai J, Zhao J, Wang Z, Zou D, Sun L. 2008. Lysis of vibrios by Bdellovibrio-and-like organisms (BALOs) isolated from marine environment. J Food Saf 28: 220-235.

Cai WL, De La Fuente L, Arias CR. 2013. Biofilm formation by the fish pathogen Flavobacterium columnare: development and parameters affecting surface attachment. Appl Environ Microbiol 79: 5633-5642.

Caporaso JG, Kuczynski J, Stombaugh J, et al. 2010. QIIME allows analysis of high-throughput community sequencing data. Nat Methods 7: 335-336.

da Costa F, Robert R, Quere C, Wikfors GH, Soudant P. 2015. Essential fatty acid assimilation and synthesis in larvae of the bivalve Crassostrea gigas. Lipids 50: 503-511.

Dobretsov S. 2009. Inhibition and induction of marine biofouling by biofilms. In: Flemming HC, Murthy PS, Venkatesan R, Cooksey K, eds. Marine and industrial biofouling. Berlin: Springer, pp. 293-313.

Foesel BU, Gieseke A, Schwermer C, et al. 2008. Nitrosomonas Nm143-like ammonia oxidizers and 5itrospira marina-like nitrite oxidizers dominate the nitrifier community in a marine aquaculture biofilm. Fems Microbiol Ecol 63: 192-204.

Furusawa G, Yoshikawa T, Yasuda A, Sakata T. 2003. Algicidal activity and gilding motility of Saprospira sp SS98-5. Can J Microbiol 49: 92-100.

Ganesan AM, Alfaro AC, Brooks JD, Higgins CM. 2010. The role of bacterial biofilms and exudates on the settlement of mussel (Perna canaliculus) larvae. Aquaculture 306: 388-392.

Gao X-Y, Xu Y, Liu Y, Liu Z-P. 2012. Bacterial diversity, community structure and function associated with biofilm development in a biological aerated filter in a recirculating marine aquaculture system. Mar Biodivers 42: 1-11.

Gatune WC, Vanreusel A, Ruwa R, Bossier P, De Troch M. 2014. Fatty acid profiling reveals a trophic link between mangrove leaf litter biofilms and the post-larvae of giant tiger shrimp Penaeus monodon. Aquac Environ Interact 6: 1-10.

Golberg K, Pavlov V, Marks RS, Kushmaro A. 2013. Coralassociated bacteria, quorum sensing disrupters, and the regulation of biofouling. Biofouling 29: 669-682.

Gonzalez-Araya R, Lebrun L, Quere C, Robert R. 2012. The selection of an ideal diet for Ostrea edulis (L.) broodstock conditioning (part B). Aquaculture 362: 55-66.

Gonzalez-Gil G, Sougrat R, Behzad AR, Lens PNL, Saikaly PE. 2015. Microbial community composition and ultrastructure of granules from a full-scale anammox reactor. Microb Ecol 70: $118-131$.

Hadfield MG. 2011. Biofilms and marine invertebrate larvae: what bacteria produce that larvae use to choose settlement sites. In: Carlson CA, Giovannoni SJ, eds, Ann Rev Mar Sci 3: 453.

Herrera M, Rodiles A, Sanchez B, Lopez JM, de La Roca E. 2016. Physiological stress responses to captivity in early developmental stages of the wedge sole Dicologoglossa cuneata (Moreau). Aquac Res 47: 732-740.

Lagos L, Herrera M, Sanchez-Lazo C, Martinez-Pita I. 2015. Effect of larval stocking density on growth, survival and whole body cortisol of the Mediterranean mussel Mytilus galloprovincialis (Lamarck, 1819) larvae reared under laboratory conditions. Aquac Res 46: 1648-1656.

Leonard N, Blancheton JP, Guiraud JP. 2000. Populations of heterotrophic bacteria in an experimental recirculating aquaculture system. Aquacult Eng 22: 109-120.

Lewin RA. 1997. Saprospira grandis: a flexibacterium that can catch bacterial prey by "ixotrophy". Microb Ecol 34: 232-263.

Li Y-F, Guo X-P, Yang J-L, et al. 2014. Effects of bacterial biofilms on settlement of plantigrades of the mussel Mytilus coruscus. Aquaculture 433: 434-441.
Lu Y, Slater F, Bello-Mendoza R, Batstone DJ. 2013. Shearing of biofilms enables selective layer based microbial sampling and analysis. Biotechnol Bioeng 110: 2600-2605.

Martins CIM, Pistrin MG, Ende SSW, Eding EH, Verreth JAJ. 2009. The accumulation of substances in Recirculating Aquaculture Systems (RAS) affects embryonic and larval development in common carp Cyprinus carpio. Aquaculture 291: 65-73.

Miranda LN, Hutchison K, Grossman AR, Brawley SH. 2013. Diversity and abundance of the bacterial community of the red macroalga Porphyra umbilicalis: did bacterial farmers produce macroalgae? PLOS ONE 8: e58269.

Moya J, Huilinir C, Peredo K, Aspe E, Roeckel M. 2012. Modeling of simultaneous denitrification - anaerobic digestion organic matter aerobic oxidation and nitrification in an anoxicanaerobicaerobic compact filter reactor. J Biotechnol 160: 176-188.

Perez V, Olivier F, Tremblay R, et al. 2013. Trophic resources of the bivalve, Venus verrucosa, in the Chausey archipelago (Normandy, France) determined by stable isotopes and fatty acids. Aquat Living Resour 26: 229-239.

Petton B, Pernet F, Robert R, Boudry P. 2013. Temperature influence on pathogen transmission and subsequent mortalities in juvenile Pacific oyster Crassostrea gigas. Aquac Environ Interact 3: 257-273.

Raulf FF, Fabricius K, Uthicke S, de Beer D, Abed RMM, Ramette A. 2015. Changes in microbial communities in coastal sediments along natural $\mathrm{CO}_{2}$ gradients at a volcanic vent in Papua New Guinea. Environ Microbiol 17: 3678-3691.

Rico-Villa B, Pouvreau S, Robert R. 2009. Influence of food density and temperature on ingestion, growth and settlement of Pacific oyster larvae, Crassostrea gigas. Aquaculture 287: 395-401.

Rico-Villa B, Woerther P, Mingant C, et al. 2008. A flow-through rearing system for ecophysiological studies of Pacific oyster Crassostrea gigas larvae. Aquaculture 282: 54-60.

Robert R, Gerard A. 1999. Bivalve hatchery technology: the current situation for the Pacific oyster Crassostrea gigas and the scallop Pecten maximus in France. Aquat Living Resour 12: 121-130.

Romero J, Garcia-Varela M, Laclette JP, Espejo R. 2002. Bacterial 16S rRNA gene analysis revealed that bacteria related to Arcobacter spp. constitute an abundant and common component of the oyster microbiota (Tiostrea chilensis). Microb Ecol 44: 365-371.

Ruan Y-J, Guo X-S, Ye Z-Y, Liu Y, Zhu S-M. 2015. Bacterial community analysis of different sections of a biofilter in a fullscale marine recirculating aquaculture system. $N$ Am J Aquacult 77: 318-326.

Rurangwa E, Verdegem MCJ. 2015. Microorganisms in recirculating aquaculture systems and their management. Rev Aquacult 7: $117-130$.

Salta M, Wharton JA, Blache Y, Stokes KR, Briand J-F. 2013. Marine biofilms on artificial surfaces: structure and dynamics. Environ Microbiol 5: 2879-2893.

Schneider O, Chabrillon-Popelka M, Smidt H, et al. 2007. HRT and nutrients affect bacterial communities grown on recirculation aquaculture system effluents. Fems Microbiol Ecol 60: 207-219.

Seidel M, Beck M, Riedel T, et al. 2014. Biogeochemistry of dissolved organic matter in an anoxic intertidal creek bank. Geochim Cosmochim Acta 140: 418-434.

Tebben J, Tapiolas DM, Motti CA, et al. 2011. Induction of larval metamorphosis of the coral Acropora millepora by tetrabromopyrrole isolated from a Pseudoalteromonas bacterium. PLOS ONE 6: e19082.

Toupoint N, Mohit V, Linossier I, et al. 2012. Effect of biofilm age on settlement of Mytilus edulis. Biofouling 28: 985-1001.

Usher KM, Kaksonen AH, Cole I, Marney D. 2014. Critical review: microbially influenced corrosion of buried carbon steel pipes. Int Biodeterior Biodegrad 93: 84-106. 
Viau VE, de Souza DM, Rodriguez EM, Wasielesky Jr W, Abreu PC, Ballester ELC. 2013. Biofilm feeding by postlarvae of the pink shrimp Farfantepenaeus brasiliensis Decapoda, Penaidae). Aquacult Res 44: 783-794.

Wang C, Bao WY, Gu ZQ, et al. 2012. Larval settlement and metamorphosis of the mussel Mytilus coruscus in response to natural biofilms. Biofouling 28: 249-256.

Xia Y, Kong Y, Nielsen PH. 2007. In situ detection of proteinhydrolysing microorganisms in activated sludge. Fems Microbiol Ecol 60: 156-165.

Yamada T, Sekiguchi Y. 2009. Cultivation of uncultured Chloroflexi subphyla: significance and ecophysiology of formerly uncultured Chloroflexi 'Subphylum I' with natural and biotechnological relevance. Microbes Environ 24: 205-216.

Yamada T, Sekiguchi Y, Hanada S, et al. 2006. Anaerolinea thermolimosa sp nov., Levilinea saccharolytica gen. nov., sp. nov. and Leptolinea tardivitalis gen. nov., so. nov., novel filamentous anaerobes, and description of the new classes anaerolineae classis nov and Caldilineae classis nov in the bacterial phylum Chloroflexi. Int J Syst Evol Microbiol 56: 1331-1340.

Yamada T, Sekiguchi Y, Imachi H, Kamagata Y, Ohashi A, Harada H. 2005. Diversity, localization, and physiological properties of filamentous microbes belonging to Chloroflexi subphylum I in mesophilic and thermophilic methanogenic sludge granules. Appl Environ Microbiol 71: 7493-7503.
Yamada T, Yamauchi T, Shiraishi K, et al. 2007. Characterization of filamentous bacteria, belonging to candidate phylum KSB3, that are associated with bulking in methanogenic granular sludges. ISME $J$ 1: 246-255.

Yang JL, Guo XP, Ding DW, et al. 2017. Interactions between natural biofilm, substratum surface wettability, and mussel plantigrade settlement. Sci China Earth Sci 60: 382-390.

Yang JL, Li YF, Guo XP, et al. 2016a. The effect of carbon nanotubes and titanium dioxide incorporated in PDMS on biofilm community composition and subsequent mussel plantigrade settlement. Biofouling 32: 763-777.

Yang JL, Li YF, Liang X, et al. 2016b. Silver nanoparticles impact biofilm communities and mussel settlement. Sci Rep 6: 37406.

Yang JL, Shen PJ, Liang X, Li YF, Bao WY, Li JL. 2013. Larval settlement and metamorphosis of the mussel Mytilus coruscus in response to monospecific bacterial biofilms. Biofouling 29: 247-259.

Zarasvand KA, Rai VR. 2014. Microorganisms: induction and inhibition of corrosion in metals. Int Biodeterior Biodegrad 87: 66-74.

Zhang G, Jiao Y, Lee D-J. 2015. Transformation of dissolved organic matters in landfill leachate bioelectrochemical system. Bioresour Technol 191: 350-354.

Zhou Z, Qiao W, Xing C, et al. 2015. Characterization of dissolved organic matter in the anoxic-oxic-settling-anaerobic sludge reduction process. Chem Eng $J$ 259: 357-363.

Cite this article as: Asmani K, Petton B, Le Grand J, Mounier J, Robert R, Nicolas J-L. 2017. Determination of stocking density limits for Crassostrea gigas larvae reared in flow-through and recirculating aquaculture systems and interaction between larval density and biofilm formation. Aquat. Living Resour. 30: 29 